\title{
Transmitter-operated Channels in Rabbit Retinal Astrocytes Studied in situ by Whole-Cell Patch Clamping
}

\author{
Beverley Clark and Peter Mobbs \\ The Department of Physiology, University College and Middlesex School of Medicine, University College, London \\ WC1E 6BT, United Kingdom
}

\begin{abstract}
Glutamate and GABA open ion channels in the membranes of astrocytes found on the vitreal surface of the rabbit retinal visual streak. The glutamate-operated channels are opened by kainate, quisqualate, and AMPA, but not by NMDA, aspartate, or the metabotropic agonist 1 -aminocyclopentane1S,3R-dicarboxylic acid. The effects of glutamate and its analogs can be blocked by $20 \mu \mathrm{m}$ 6-cyano-7-nitroquinoxaline-2,3-dione. The conductance increase evoked by $10 \mu \mathrm{M}$ glutamate, a concentration of this transmitter near to that found in the vitreous humor that bathes these cells, was equivalent to $22 \%$ of the cell's resting conductance. The conductance increase evoked by $1 \mu \mathrm{M}$ GABA, a concentration near that found in the vitreous, was equivalent to $131 \%$ of the cell's resting conductance. The effects of GABA can be blocked by bicuculline. These data show that GABA, and non-NMDA-type glutamate receptors play an important part in determining the resting potential of visual streak astrocytes in situ and that these channels may be of general importance for the functions of astrocytes in vivo.
\end{abstract}

Glutamate and GABA are major neurotransmitters of the CNS, and their actions on neurons are well known. However, their effects on glia have largely been studied on cells in short- or long-term culture and are less well understood. In acutely dissociated amphibian and mammalian Müller cells, glutamate generates an inward current by activating an electrogenic uptake mechanism in which glutamate is transported into cells in association with an excess of sodium ions (Brew and Attwell, 1987; Sarantis and Attwell, 1990). Electrogenic uptake of glutamate has also been described for cultured type 1 cerebellar astrocytes (Cull-Candy et al., 1988). In cultured type 2 and also type 1 cerebellar astrocytes held in longer-term culture $(>7 \mathrm{~d})$, glutamate produces an inward current by opening channels similar to those found in neurons operated by glutamate, quisqualate, AMPA, and kainate (Kettenmann and Schachner, 1985; Sontheimer et al., 1988; Usowicz et al., 1989; Wyllie et al., 1991). Like glutamate, GABA can also produce membrane currents either as the result of uptake driven by the sodium gradient as shown for skate horizontal cells (Malchow and Ripps, 1990) or

Received July 23, 1991; revised Sept. 23, 1991; accepted Sept. 27, 1991.

We thank Mike Neal and Jo Cunningham for HPLC analysis of vitreous humor samples. This work was supported by the Wellcome Trust, the Medical Research Council of Great Britain, and the Wolfson Foundation.

Correspondence should be addressed to Peter Mobbs, The Department of Physiology, University College and Middlesex School of Medicine, University College, Gower Street, London WC1E 6BT, UK.

Copyright (C) 1992 Society for Neuroscience $0270-6474 / 92 / 120664-10 \$ 05.00 / 0$ by opening chloride channels (Bormann et al., 1987). GABA has been shown to open chloride channels via an action on $\mathrm{GABA}_{\mathrm{A}}$ receptors in cultured rat cortical astrocytes (Kettenmann and Schachner, 1985; Bormann and Kettenmann, 1988) and isolated skate Müller cells (Malchow et al., 1989).

The transmitter uptake carriers found in astrocytes are thought to be important for the termination of transmitter action (Hertz, 1979) and perhaps for transmitter release through reversal of the normal uptake mechanism (Schwartz, 1987; Szatkowski et al., 1990). The physiological significance of transmitter-operated channels in glial cells is not understood, although roles in the regulation of excitability at nodes of Ranvier (Usowicz et al., 1989), potassium accumulation (Ballanyi et al., 1987), and long-range signaling between glial cells involving glutamate-mediated calcium entry (Cornell-Bell et al., 1990) have all been suggested.

The object of the work presented here was to investigate the properties of the transmitter-gated currents of retinal astrocytes in situ. The experiments were necessary for two reasons: first, to validate studies in culture, because glial cell phenotype, including the nature of the ion channels expressed, depends on culture conditions (Raff et al., 1983; Barres et al., 1988), and second, to determine the properties of this important class of glial cells associated with the retinal circulation. In this study, we have utilized a preparation of the rabbit retinal visual streak in which it is possible to whole-cell patch clamp astrocytes in $s i t u$ in isolated flat-mounted retinas.

\section{Materials and Methods}

Whole-cell patch-clamp recording. Flat-mount preparations of the visual streak region of the rabbit retina were prepared as described in detail elsewhere (Clark and Mobbs, 1990; Lightman and Mobbs, 1990). Briefly, a piece of retina was cut from the eye so as to include part of the visual streak. This was washed free of vitreous humor and then placed, vitreal surface up, over a window of coverslip glass inserted into a hole cut in a Millipore filter. The window allowed for substage illumination of the tissue and observation from above with a water-immersion objective. Most retinas were treated for 5-20 min with a solution containing $2 \mathrm{mg} / \mathrm{ml}$ collagenase (Cooper-Biomedical L5000476), $1.2 \mathrm{mg}$ $\mathrm{ml}$ hyaluronidase (Sigma H2376), and $0.3 \mathrm{mg} / \mathrm{ml}$ trypsin inhibitor (Sigma T9253). The enzymes were added to the normal Ringer's solution used to superfuse the retina during whole-cell recording. the Ringer's solution contained (in $\mathrm{mM}$ ) $\mathrm{NaCl}, 140 ; \mathrm{KCl}, 2.5 ; \mathrm{CaCl}_{2}, 3.0 ; \mathrm{MgCl}_{2}, 0.5$; HEPES, 5; and glucose, 15 (the $\mathrm{pH}$ was brought to 7.4 using $1 \mathrm{M} \mathrm{NaOI}$ ). Patch-pipettes were pulled from thick-wall borosilicate glass (Clark Electromedical type GC150F-10). Pipettes were filled with a solution containing (in mM) KCl, 120; $\mathrm{MgCl}_{2}, 7 ; \mathrm{K}_{2}$-EGTA, 5; $\mathrm{NaCl}, 5 ; \mathrm{Na}_{2}$-ATP, 5; HEPES, 5; and $\mathrm{CaCl}_{2} 1$ (the $\mathrm{pH}$ was brought to 7.2 with $\mathrm{KOH}$ ). In experiments to establish the reversal potential of GABA-evoked currents, the chloride concentration in the pipette was varied by substitution of $\mathrm{K}$-acetate for $\mathrm{KCl}$ to give solutions containing $10 \mathrm{~mm}$ and 37 
mM chloride in addition to the normal internal solution chloride concentration of $141 \mathrm{~mm}$. All internal solutions additionally contained 1.0 $\mathrm{mg} / \mathrm{ml}$ of Lucifer yellow $\mathrm{CH}$. When filled with internal solution, patch pipettes typically had resistances of 5-10 $\mathrm{M} \Omega$. All voltages have been corrected for the junction potentials due to the difference in the ionic composition of internal and external solutions (Fenwick et al., 1982). The Ringer's solution and solutions containing drugs were applied to the cells by perfusion of the space beneath the water-immersion objective via a small-diameter pipette. Drugs used were GABA (Sigma A2129), bicuculline (Sigma B6889), glutamate (Sigma G1626), kainate (Sigma K0250), quisqualate (Tocris Neuramin, Bristol, U.K.), (S)-AMPA (Tocris), 6-cyano-7-dinitroquinoxaline-2,3-dione (CNQX) (Tocris), and 1 -aminocyclopentane-1S,3R-dicarboxylic acid (trans-ACPD) (Tocris).

In the studies described below, we recorded from more than 300 cells. For 54 of these cells in which we measured the zero current potential, the apparent resting potential was $-59 \pm 3.5 \mathrm{mV}$ (more negative than $-75 \mathrm{mV}$ in $31 \%$ of cells). After correcting for the shunt formed by the seal resistance (Tessier-Lavigne et al., 1988), the mean resting potential was $-70 \pm 4.8 \mathrm{mV}$ (more negative than $-75 \mathrm{mV}$ in $50 \%$ of cells). The input resistance and the cell membrane capacitance were determined from analysis of the current transients resulting from $-10 \mathrm{mV}$ voltage pulses from a holding potential of $-75 \mathrm{mV}$. The decay in the current transient following such voltage steps was well described by a single exponential, suggesting that the long (up to $75 \mu \mathrm{m}$ ) processes of the cells did not constitute a significant internal resistance and that the cells were adequately space clamped. The input resistance and membrane capacitance were $558 \pm 63.6 \mathrm{M} \Omega$ and $19.5 \pm 1.8 \mathrm{pF}$, respectively. Although we cannot rule out the possibility that visual streak astrocytes are coupled by gap junctions, we saw no evidence of dye-coupling in our experiments. Seal resistances were typically greater than $10 \mathrm{G} \Omega$. All data are taken from cells for which the access resistance was less than $30 \mathrm{M} \Omega$ (mean for all cells was $45.5 \pm 5.55 \mathrm{M} \Omega$ ). The data have been corrected for voltage errors caused by current flow through the access resistance. Numerical values quoted are means $\pm S E M$.

Identification of cells. The endothelial cells that form the capillaries of the visual streak are associated with two other cell types, pericytes and astrocytes. These two cell types can be distinguished using both morphological and immunohistochemical criteria. All astrocytes express glial fibrillary acidic protein (GFAP), while other CNS cells do not (Bignami and Dahl, 1977). The morphological criteria under which astrocytes can be differentiated from pericytes have been described in detail elsewhere (Stensaas, 1975; Lightman and Mobbs, 1990). In brief, the cell bodies of pericytes lie on capillaries, and their processes (which have a characteristic peglike appearance) wrap around, and are confined to, the capillary surface. These cells are GFAP negative. The astrocytes we recorded had cell bodies located away from the capillaries and had branches that terminated in endfoot processes on nearby capillaries. Using the technique and the antibody to GFAP developed by Watanabe and Raff(1988), we were able to show that all cells with this morphology are GFAP positive and can thus be classified as astrocytes (Fig. 1B). Schnitzer and Karschin (1986) have previously described GFAP-positive cells in similar locations in the rabbit retina, and a recent study of astrocyte morphology in the rabbit retina has shown that rabbit visual streak astrocytes fall into several distinct anatomical classes (Robinson and Dreher, 1989). The cells we recorded were of Robinson and Dreher's classes B and C; none were "perivascular astrocytes" (their class A GFAP-positive cells). These were excluded by choosing to record cells with their cell bodies located away from capillaries to avoid any possible confusion with pericytes, which have cell bodies in similar positions to "perivascular astrocytes." We used the Lucifer yellow incorporated in the internal solution to check routinely upon the identity of our cells. Figure $1 A$ shows a typical visual streak astrocyte filled with Lucifer yellow. The responses of astrocytes to GABA and glutamate were similar regardless of morphology.

\section{Results}

\section{GABA-operated chloride channels}

We examined the responses of the rabbit visual streak astrocytes to GABA. GABA produced responses in all 28 cells tested. With $141 \mathrm{~mm}$ chloride in the patch pipette, the GABA-evoked current was inward at negative potentials, reversed at $+0.4 \mathrm{mV}(n=$ 2 ), and became outward at more positive potentials (Fig. $2 A$ ). The $I-V$ relation for GABA was linear (Fig. $2 B$ ).
Several lines of evidence show that the GABA-evoked current in these cells results from the opening of chloride channels as it does in mammalian central neurons (Krnjević and Schwartz, 1967) and cultured astrocytes (Bormann and Kettenmann, 1988) rather than from the operation of an uptake carrier. The reversal potential for the GABA-gated conductance showed an approximately Nernstian dependence on the chloride concentration gradient: with normal Ringer's solution outside and $141 \mathrm{~mm}$ chloride $\left(E_{\mathrm{cl}}=+1.4 \mathrm{mV}\right)$ in the patch pipette, the reversal potential was $+0.4 \mathrm{mV}(n=2)$; with an internal solution containing $37 \mathrm{~mm}$ chloride $\left(E_{\mathrm{cl}}=-34.1 \mathrm{mV}\right)$, it was $-25.5 \pm 2.3$ $\mathrm{mV}(n=3)$; and for $10 \mathrm{mM}$ chloride $\left(E_{\mathrm{cl}}=-67.7 \mathrm{mV}\right)$, it was $-59.6 \pm 1.9 \mathrm{mV}(n=3)$. Deviation from perfect Nernstian behavior may be explained by the permeability of GABA-gated chloride channels to acetate (Bormann et al., 1987), the anion used to replace chloride in these experiments. Bicuculline, a potent antagonist of the $\mathrm{GABA}_{\mathrm{A}}$ channel found in neurons, applied at a concentration of $50 \mu \mathrm{M}$ caused a $77 \%$ reduction in the size of the GABA-evoked current in the cell shown in Figure 3. The residual current reversed at the same potential as the current produced by GABA in the absence of bicuculline (data not shown), suggesting that it arises from the operation of GABA channels that remained unblocked by the antagonist rather than from the operation of an electrogenic uptake mechanism similar to that described for skate retinal horizontal cells (Malchow and Ripps, 1990). The application of GABA was associated with an increase in membrane current noise (Fig. 4) as expected to result from the operation of ligand-gated channels.

\section{The GABA dose-response relationship}

Dialysis probe measurements show that GABA occurs in the preretinal vitreous fluid of the rabbit eye at concentrations of 1 $\mu \mathrm{M}$ (Gunnarson et al., 1987). The GABA content of vitreous taken from eyes used in our experiments 10 min postmortem was much higher $(15.5 \pm 3.7 \mu \mathrm{M} ; n=4)$ (M. Neal and J. Cunningham, personal communication), probably reflecting the increase in release of GABA known to occur in the brain during an anoxic insult (Hagberg et al., 1985).

We examined the relationship between concentration and the size and time course of the GABA response. No densensitization was apparent for GABA applications of $3 \mu \mathrm{M}$ and less over a period of $40 \mathrm{sec}$. Desensitization was apparent in currents evoked by GABA concentrations of greater than $10 \mu \mathrm{M}$ (Fig. $5 A$ ). However, after $20 \mathrm{sec}$, the time taken for the response to high concentrations of GABA to reach steady state, a substantial GABAevoked current remained and was maintaincd for $5 \mathrm{~min}$, the longest period for which high concentrations of GABA were applied. The densensitization produced by GABA was long lasting and reduced the size of subsequent responses to applications of the drug for several minutes. The dose-response curve for the steady-state GABA-evoked current is shown in Figure $5 B$. The $\mathrm{EC}_{50}$ for GABA was $18.5 \mu \mathrm{M}$.

The conductance change produced by application of $1 \mu \mathrm{M}$ GABA $\left(G_{\mathrm{GABA}}\right)$, a concentration similar to that found in the vitreous, was calculated as

$$
G_{\mathrm{GABA}}=I_{\mathrm{GABA}} / V_{\mathrm{HOLD}}-V_{\mathrm{REV}},
$$

where $I_{\mathrm{GABA}}$ was the current evoked by $1 \mu \mathrm{M} \mathrm{GABA}, V_{\mathrm{REV}}$ was the reversal potential for the GABA-evoked current, and $V_{\text {HOLD }}$ was the holding potential $(-75 \mathrm{mV}) . G_{\mathrm{GABA}}$ represented $131 \pm$ $26.3 \%(n=6)$ of the cells' resting conductance estimated from 

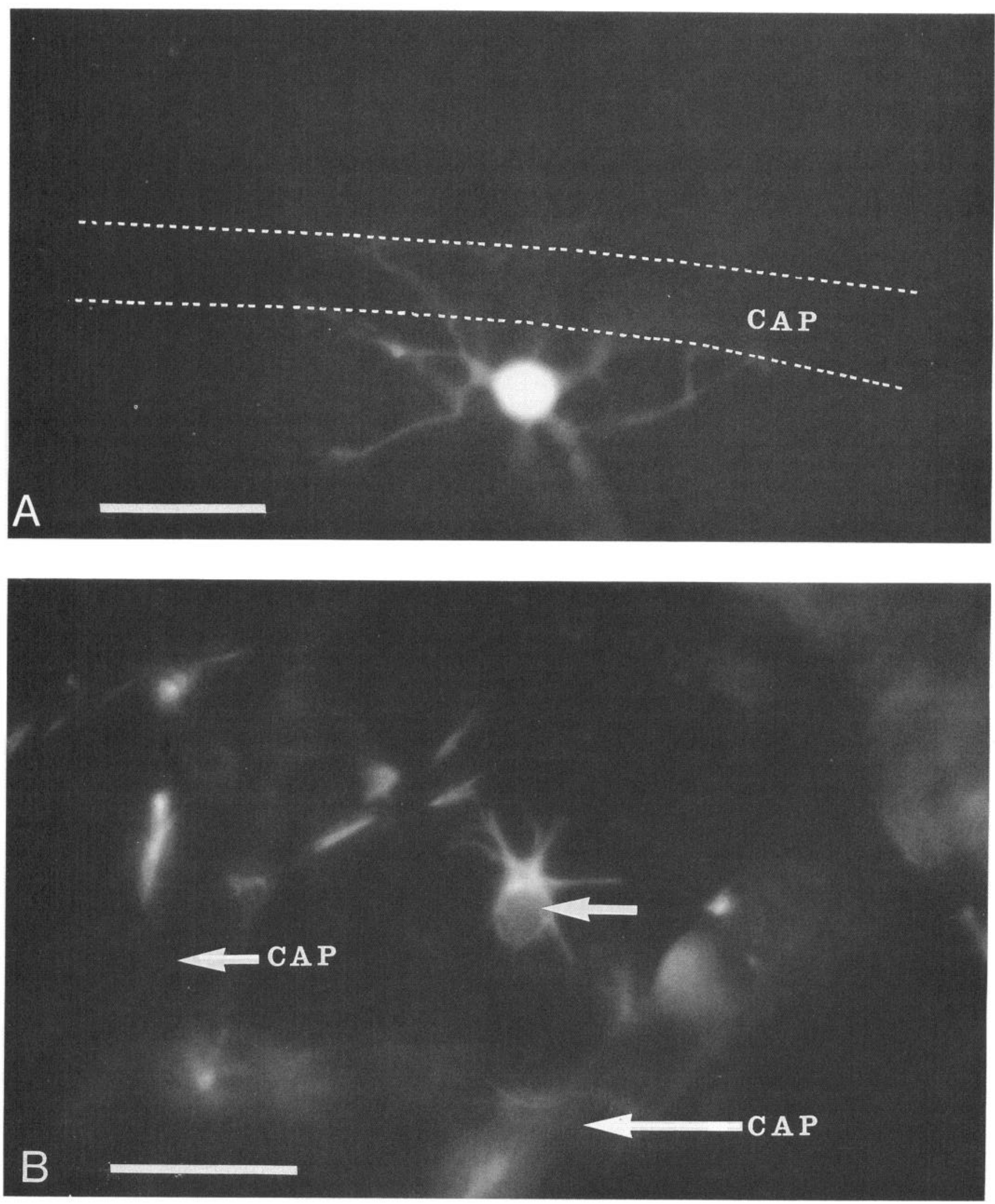

Figure 1. Identification of visual streak astrocytes. $A$, A visual streak astrocyte filled with Lucifer yellow from the patch pipette and viewed by light from the epifluorescence illuminator. Processes radiate out from the cell body to make contact with a nearby capillary $(C A P)$. $B$, A visual streak astrocyte (arrow) labeled with an antibody to GFAP. Two nearby capillaries $(C A P)$ are indicated. GFAP-labeled cells had the same range of morphologies as those labeled with Lucifer yellow during whole-cell recording. Scale bars, $20 \mu \mathrm{m}$. 

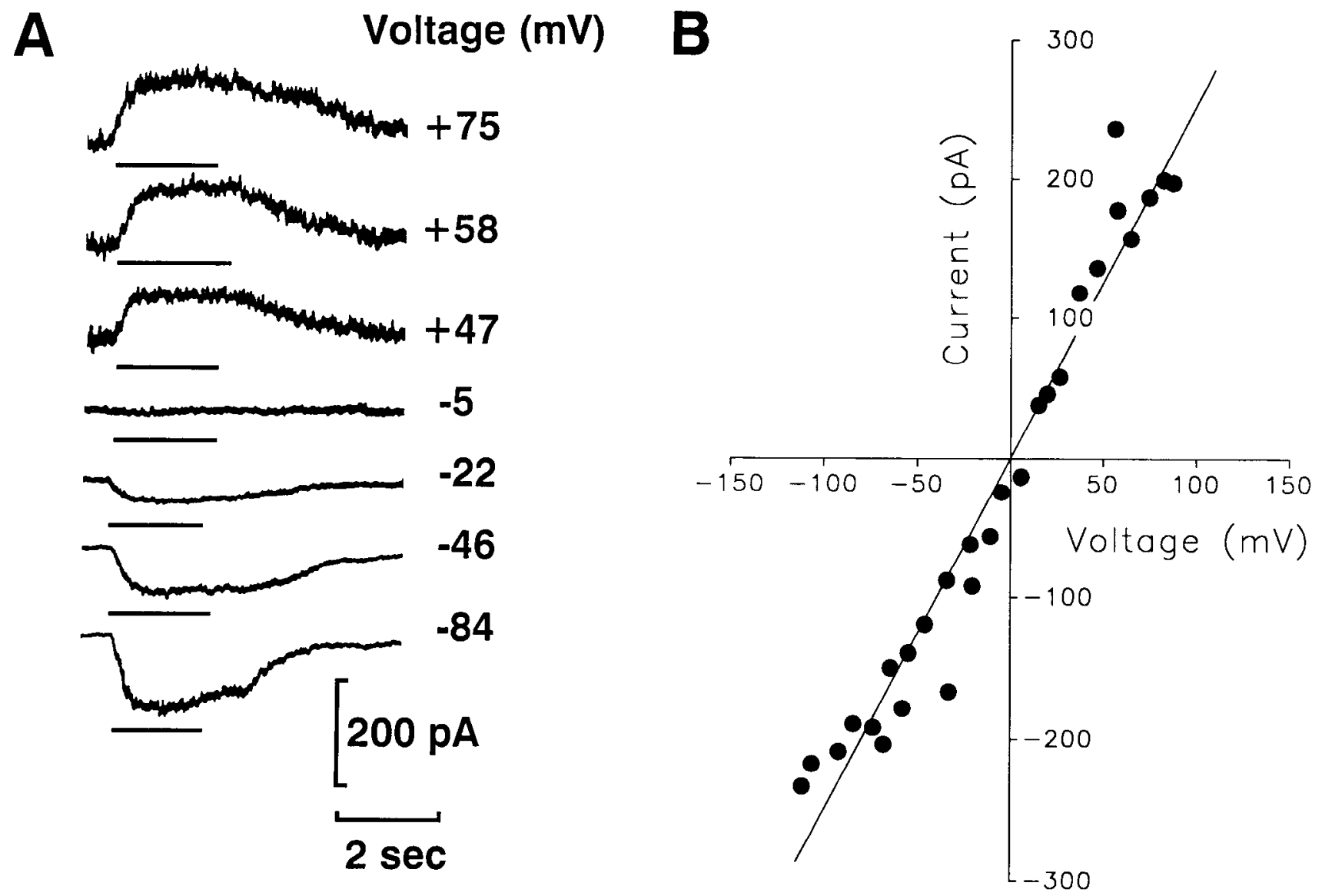

Figure 2. The current-voltage relationship for the GABA-evoked current. $A$, the response of a visual streak astrocyte to local perfusion of 100 $\mu \mathrm{M}$ GABA at a series of different holding potentials. The timing of GABA application is shown by the bar below each trace. The increased noise in the traces at positive potentials is probably due to the activation of voltage-gated potassium channels. The internal solution contained $141 \mathrm{~mm}$ $\mathrm{Cl}^{-}$. B. The current-voltage relation for the GABA-evoked current measured at the end of the shortest period of application (1.75 sec). Sample data for this cell are shown in $A$. The solid line is a least-squares fit to the data. The mean reversal potential for two cells with $141 \mathrm{~mm} \mathrm{Cl}^{-}$internal was $+0.4 \mathrm{mV}$.

the current evoked by voltage steps $(-10 \mathrm{mV}$ at a holding potential of $-75 \mathrm{mV}$ ) in the absence of the drug.

\section{Distribution of GABA receptors}

We examined the possibility that $\mathrm{GABA}$ receptors might be spatially localized in the astrocyte membrane. To test this hypothesis we used ionophoretic applications of GABA to map the distribution of GABA receptors. Figure 6 shows the results of one experiment in which GABA was ejected at five different locations near the membrane of an astrocyte. The cell was filled with Lucifer yellow to facilitate location of its processes. The ionophoretic pipette was maneuvered up to the cell using a combination of UV light to illuminate the dye-filled cell and dim white light to position the ionophoretic pipette. The cells were continuously superfused with Ringer's solution to reduce the background level of the drug in the bath and its diffusion to other regions of the cell. The left side of Figure 6 shows the cell we mapped filled with Lucifer yellow; the positioning of the ionophoretic electrode during GABA delivery is indicated on the right side.

Responses were obtained to ionophoretic pulses of GABA applied along the length of processes (position 1), to the soma (position 3), and to the ends of branches (positions 4 and 5). No response was obtained either when the pipette was withdrawn from the cell membrane a short distance (position 2) or when the electrode was lifted $25 \mu \mathrm{m}$ above the retinal surface (not shown). This result indicates that the responses seen during application of GABA to cell processes did not arise from diffusion of the drug to the soma. We have not attempted to estimate the density of receptors at different points on the cell surface. However, while GABA receptors appear to be present

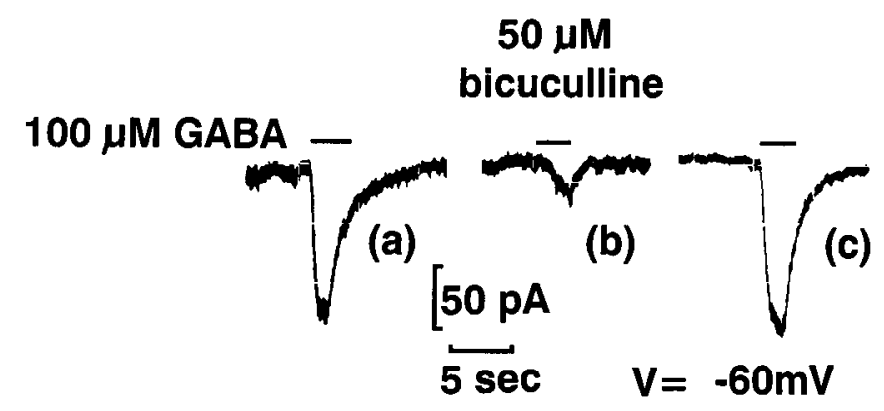

Figure 3. Bicuculline blocks the GABA-evoked current. (a), The response to GABA application of a visual streak astrocyte held at -60 $\mathrm{mV}$ with $141 \mathrm{~mm} \mathrm{Cl}^{-}$in the patch pipette. (b), Response to GABA in the presence of $50 \mu \mathrm{M}$ bicuculline. The residual current in bicuculline reversed at the same potential as did the GABA-evoked current in Ringer's, suggesting that it arises from channels that remain unblocked (data not shown). (c), Response to GABA on return to normal Ringer's solution. The timing of drug application is shown by the bars above the traces. 


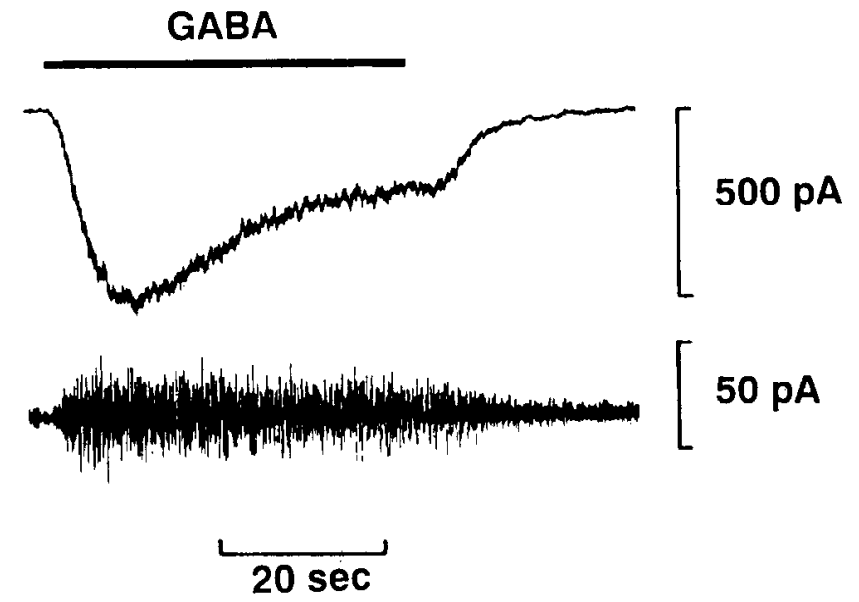

Figure 4. The response to GABA is associated with a large increase in membrane current noise. The top trace shows the response evoked by $30 \mu \mathrm{M}$ GABA (the timing of the application is shown by the bar) at $-75 \mathrm{mV}$ with $14 \mathrm{I} \mathrm{mM} \mathrm{Cl}^{-}$in the pipette. The data have been low-pass filtered at $256 \mathrm{~Hz}$. The lower trace shows the same data as above but at higher gain after high-pass filtering at $1 \mathrm{~Hz}$ (eight-pole Butterworth) to better show the noise increase. in the surface membrane of all regions of the cell, the response at position 4 is nearly as large as that from the cell body, although the surface area of the process affected by the drug at this point must have been small. This suggests that the receptor density on cell processes may be greater than at the cell body.

\section{Glutamate-operated ion channels}

We examined the responses of astrocytes held in whole-cell voltage clamp to the application of glutamate and glutamate analogs. Glutamate, kainate, quisqualate, or AMPA produced inward currents at negative potentials in $89 \%$ of the 86 cells that we tested. Four lines of evidence show that these currents must arise from the opening of glutamate-gated channels rather than from the operation of an uptake mechanism such as that described for cultured type 1 astrocytes (Cull-Candy et al., 1988) and Müller cells (Brew and Attwell, 1987). First, the currentvoltage $(I-V)$ relationships for glutamate and kainate-evoked currents (Fig. $7 A, B$ ) were ohmic or outwardly rectifying with a reversal potential of $0 \pm 2.3 \mathrm{mV}(n=10)$. Second, application of glutamate was associated with a substantial noise increase (Fig. 8), as expected for the opening and closing of ion channels. Third, applications of $100 \mu \mathrm{M}$ kainate, quisqualate, and AMPA all produced inward currents at negative potentials (Fig. 9B) with an $I-V$ relationship and reversal potential similar to those produced by glutamate (data not shown). Application of 100

\section{A}
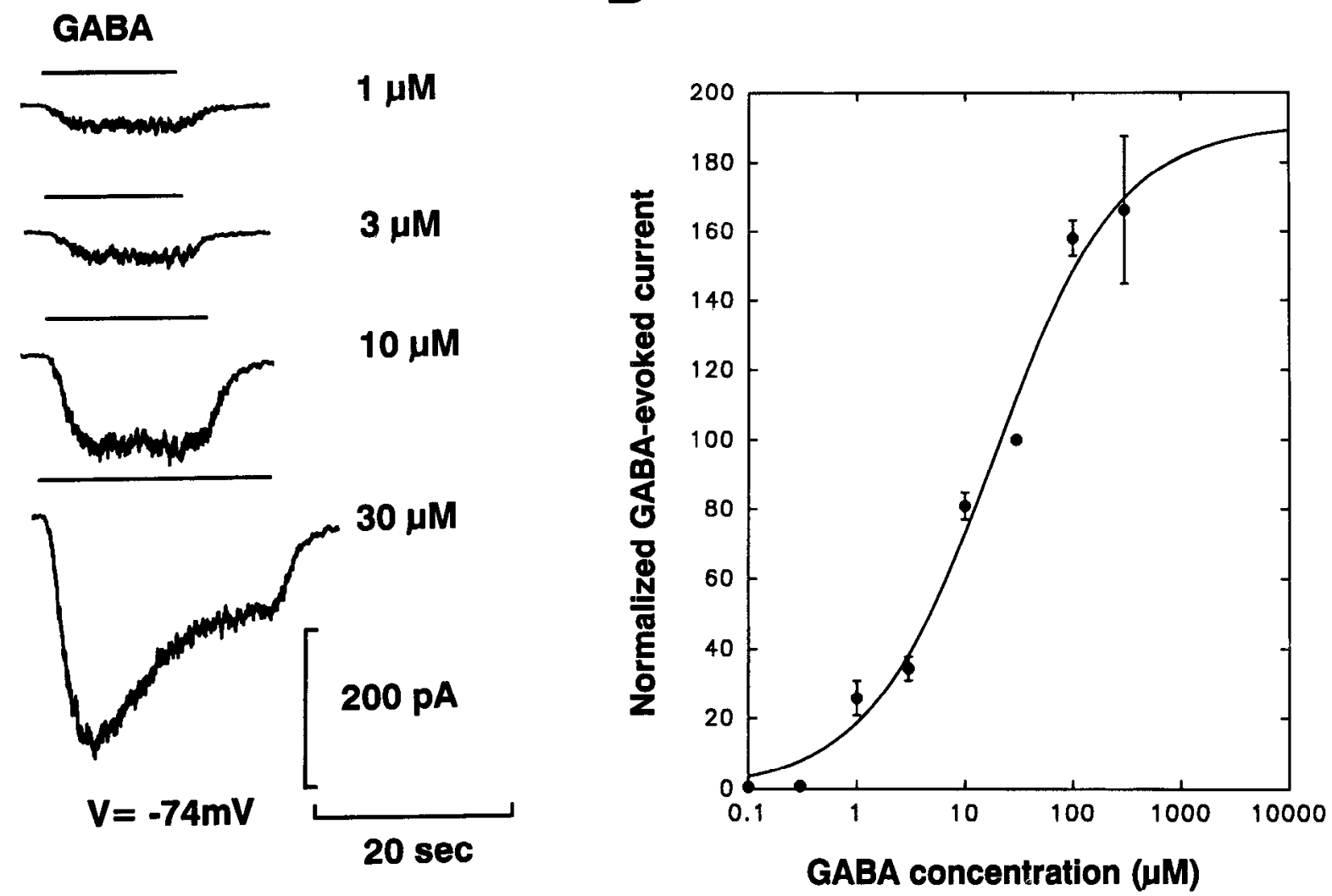

Figure 5. The GABA dose-response relationship. $A$, The responses of an astrocyte to the application of increasing concentrations of GABA. Holding potential, $-74 \mathrm{mV}$. The timing of a drug application is shown by the bar above each trace. $B$, A steady-state dose response curve for GABA constructed from data like those shown in $A(100 \mathrm{nM}, n=2 ; 300 \mathrm{nM}, n=1 ; 1,3$, and $10 \mu \mathrm{M}, n=3$ each; $30 \mu \mathrm{M}, n=8 ; 100$ and $300 \mu \mathrm{M}$, $n=5$ each). The results are shown normalized to the response at $30 \mu \mathrm{M}$. The line through the data is the logistic equation $f=I_{\max }\left[1.0 / 1.0+\left(\mathrm{EC}_{50} f\right.\right.$ dose)] ${ }^{\text {Hill }}$ with an $\mathrm{EC}_{50}$ for GABA of $18.5 \mu \mathrm{M}$ and a Hill coefficient of 0.8 . 


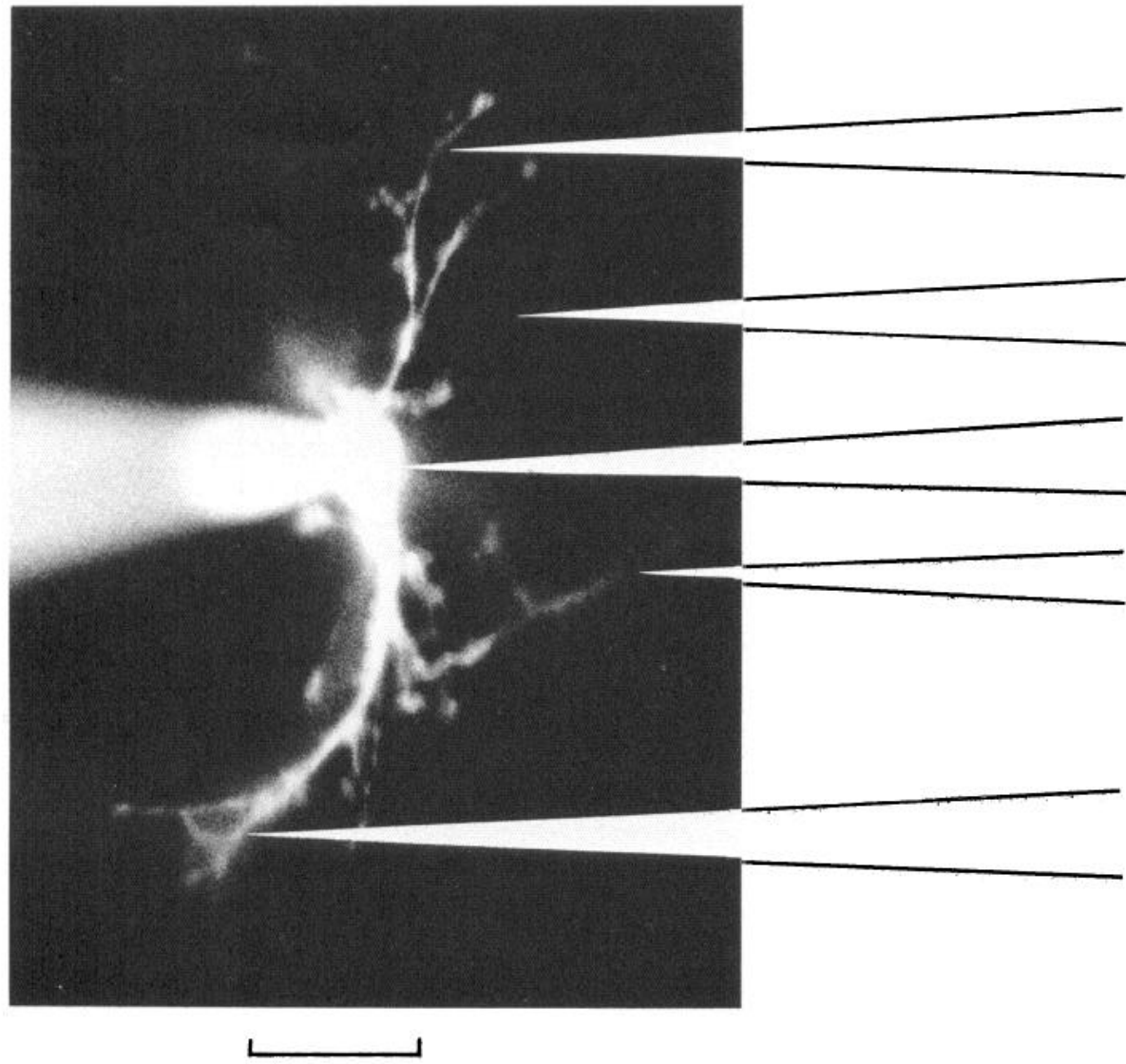

$25 \mu \mathrm{m}$

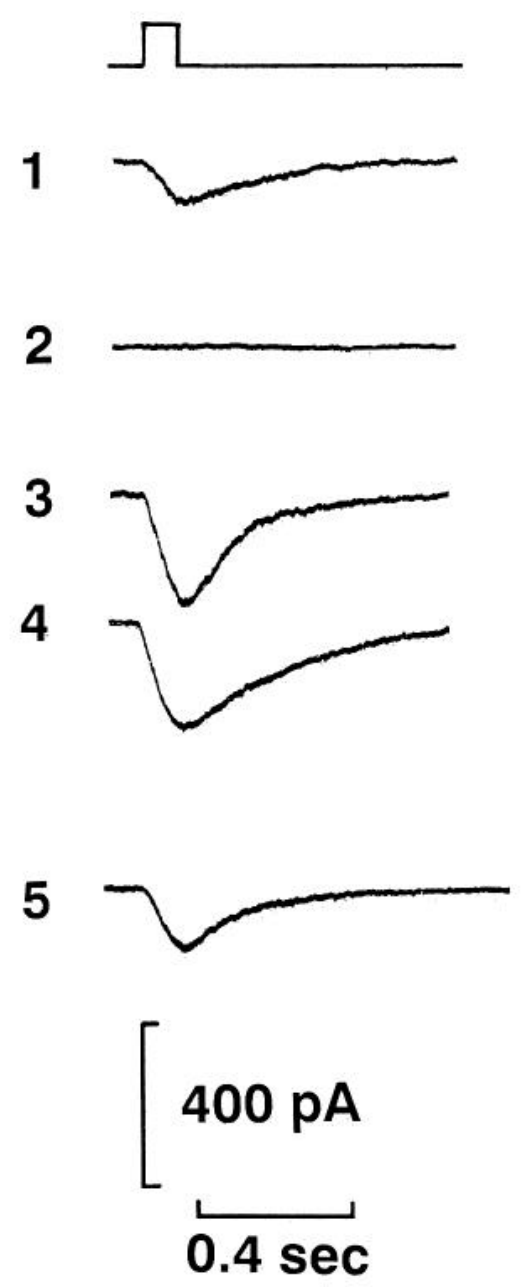

$0.4 \mathrm{sec}$

Figure 6. The distribution of receptors on an astrocyte mapped by means of the ionophoretic application of short-duration pulses of GABA. The cell shown on the left was filled with Lucifer yellow from the patch pipette, which can be seen attached to the cell on the left side of its cell body. GABA was applied at six locations, five of which are indicated (1-5). The current responses are shown on the right. Large responses were obtained from the cell body (position 3), along the length of branches (position 4), and also from terminal processes (positions 1 and 5). In position 2, the ionophoretic electrode was withdrawn $20 \mu \mathrm{M}$ from the cell membrane; no response was obtained at this distance. Lifting the electrode $30 \mu \mathrm{m}$ also abolished the response. The timing of the ionophoretic constant current pulse (retain current, $30 \mathrm{nA}$; eject current, $15 \mathrm{nA}$ ) is shown on the right above the current traces.

$\mu \mathrm{M}$ NMDA (Fig. 9A) and $100 \mu \mathrm{M}$ aspartate (not shown) was without effect even when NMDA was applied in the presence of $1 \mu \mathrm{M}$ glycine and the absence of magnesium. The "metabotropic" agonist trans-ACPD (30 $\mu \mathrm{M})$ also had no effect on the membrane current (data not shown). Fourth, the response to glutamate and its analogs was greatly reduced in the presence of the glutamate antagonist CNQX (Fig. 9C). In contrast, the $I-V$ relation for glutamate uptake shows strong inward rectification and does not reverse even at potentials as positive as $+80 \mathrm{mV}$, and in addition, operation of the uptake carrier is not associated with a large increase in noise, is not activated by kainate, and is not inhibited by CNQX (Barbour et al., 1991). For these reasons we attribute the currents evoked in our astrocytes by glutamate and its analogs to the presence of receptors similar to the AMPA/kainate types found in neurons (for review, see Watkins et al., 1990) and cultured type 2 astrocytes (Usowicz et al., 1989; Wyllie et al., 1991).

\section{Glutamate dose-response relationship}

Analyses of the amino acid content of the preretinal vitreous space in the eye of rabbits using dialysis probes has shown that glutamate is found at a concentration of approximately $10 \mu \mathrm{M}$ in the vitreous fluid that bathes visual streak astrocytes (Gunnarson et al., 1987). The concentration of neurotransmitters in the extracellular space of the brain rises massively during ischemia (Hagberg et al., 1985); such increases probably also occur in the eye and may account for the much higher concentrations of glutamate $(170 \mu \mathrm{M})$ reported to be present in vitreous fluid withdrawn from postmortem eyes (Reddy et al., 1961).

We investigated the relationship between concentration and the size and time course of the glutamate-evoked current in our cells. Responses to $10 \mu \mathrm{M}$ glutamate, the concentration found in the vitreous, showed no signs of desensitization (longest period of application, $70 \mathrm{sec}$ ), and produced conductance increases (calculated as described above for GABA) equivalent to $22 \pm$ $5.5 \%(n=4)$ of the cell's resting conductance (Fig. 10A). Slow desensitization was apparent in the responses of some cells to doses of $100 \mu \mathrm{M}$ glutamate and was present in all cells at concentrations of $300 \mu \mathrm{M}$ and $1 \mathrm{mM}$ (Fig. 10A). However, a substantial steady-state response was reached after 10-20 sec of application, and this was sustained for $20 \mathrm{~min}$, the longest period for which recordings were continued in these experiments. The 
A

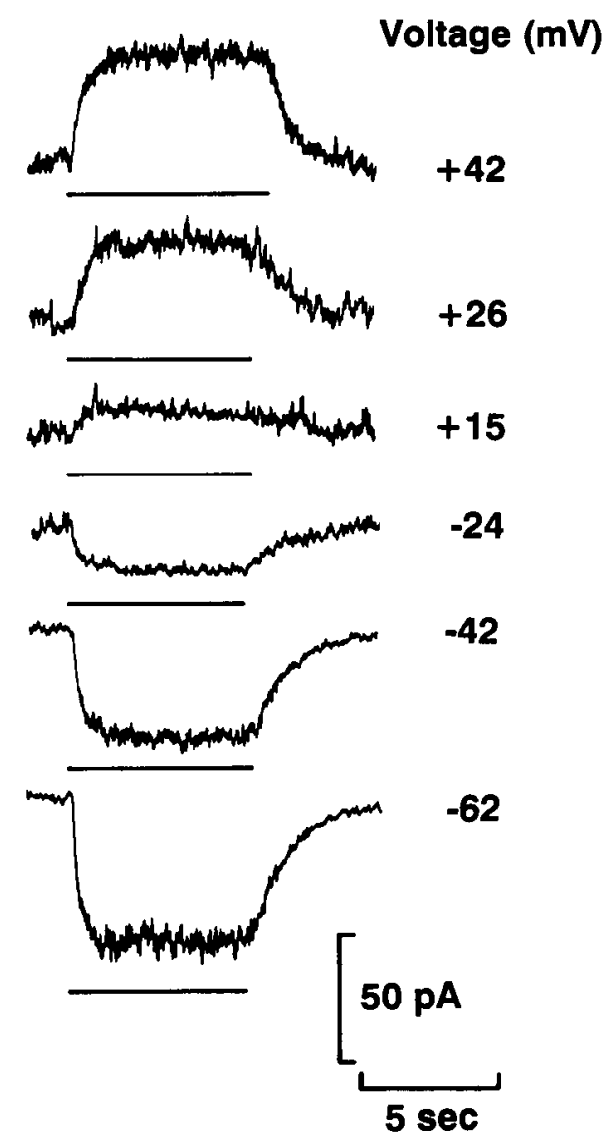

B

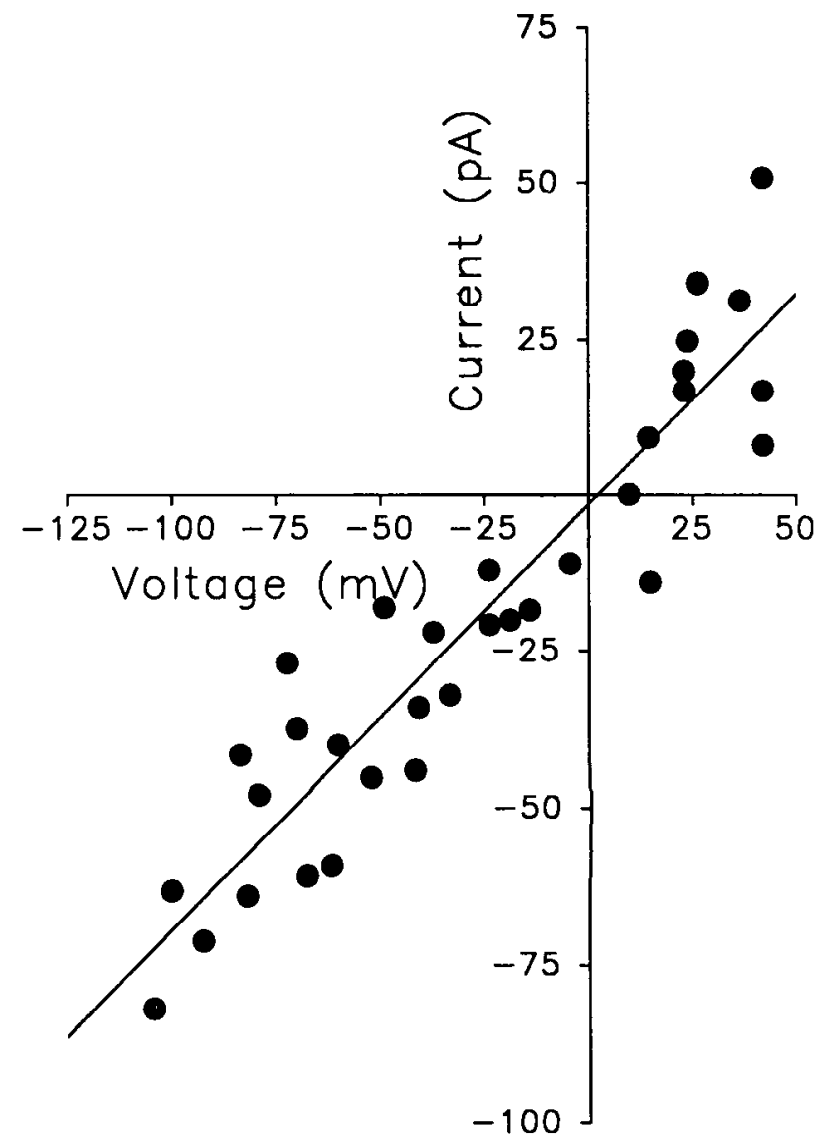

Figure 7. Current-voltage relationship for the glutamate-evoked current. $A$, Responses of an astrocyte held in whole-cell voltage clamp to the local perfusion of $100 \mu \mathrm{M}$ glutamate at a series of different holding potentials. The traces at more positive potentials are noisier than those at negative ones presumably due to the activation of voltage-gated potassium channels. The timing of glutamate application is shown by the bars beneath each trace. $B$, The current-voltage relation for the glutamate-evoked current measured at the offset of the shortest period of application $(6.5 \mathrm{sec})$. Sample data for this cell are shown in $A$. The solid line is a least-squares fit to the data. The mean reversal potential for the glutamateevoked current was $0 \pm 2.3 \mathrm{mV}(n=10)$.

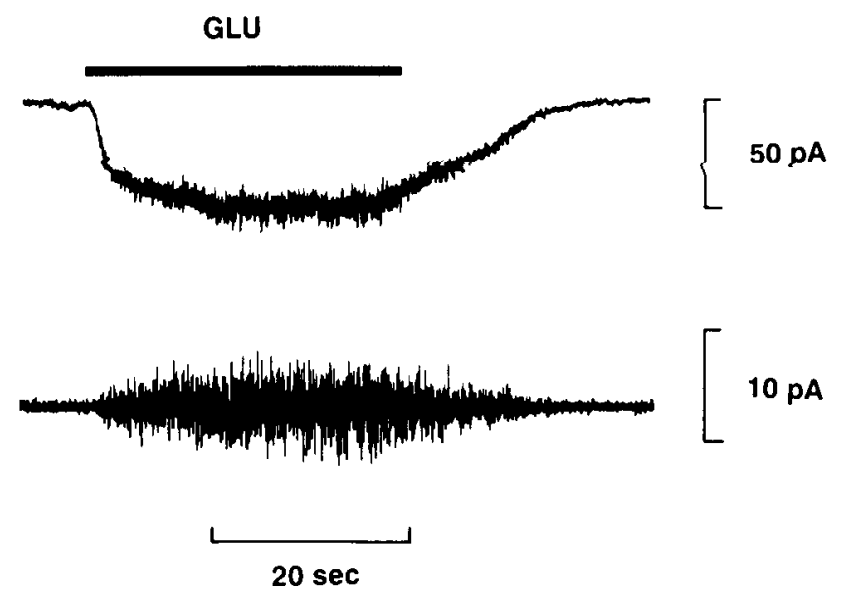

Figure 8. The glutamate-evoked increase in membrane current noise. The response to glutamate and its analogs is associated with a large increase in membrane current noise. The top trace shows the response produced in an astrocyte held at $-75 \mathrm{mV}$ application of $100 \mu \mathrm{M}$ glutamate (timing of application shown by the bar above). The data have been low-pass filtered at $256 \mathrm{~Hz}$. The bottom trace shows the same glutamate-evoked current at higher gain after high-pass filtering at $1 \mathrm{~Hz}$ (eight-pole Butterworth). dose-response curve for glutamate is shown in Figure $10 B$. The $\mathrm{EC}_{s s}$ for glutamate was $21.5 \mu \mathrm{M}$.

\section{Distribution of glutamate receptors}

Glutamate, in addition to bcing found in the vitreous fluid bathing rabbit retinal astrocytes, is released from the axons of glutamatergic neurons (Wheeler et al., 1966; Weinreich and Hammerschlag, 1975; Lieberman et al., 1989). We considered the possibility that glutamate receptors might be localized on the branches of astrocytes with processes on, or near, the ganglion cell axon bundles en route to the optic nerve. We used ionophoretic application of glutamate to map the distribution of receptors on astrocytes (procedure as for GABA above). Glutamate receptors were present at all regions tested, and there was no indication that they were concentrated on processes proximal or distal to the capillaries with which the cells were associated. Responses of similar magnitude were obtained from both cell bodies and some cell processes, suggesting, as for the distribution of GABA receptors, that the receptor density may be greater on certain branches than on the cell body. 

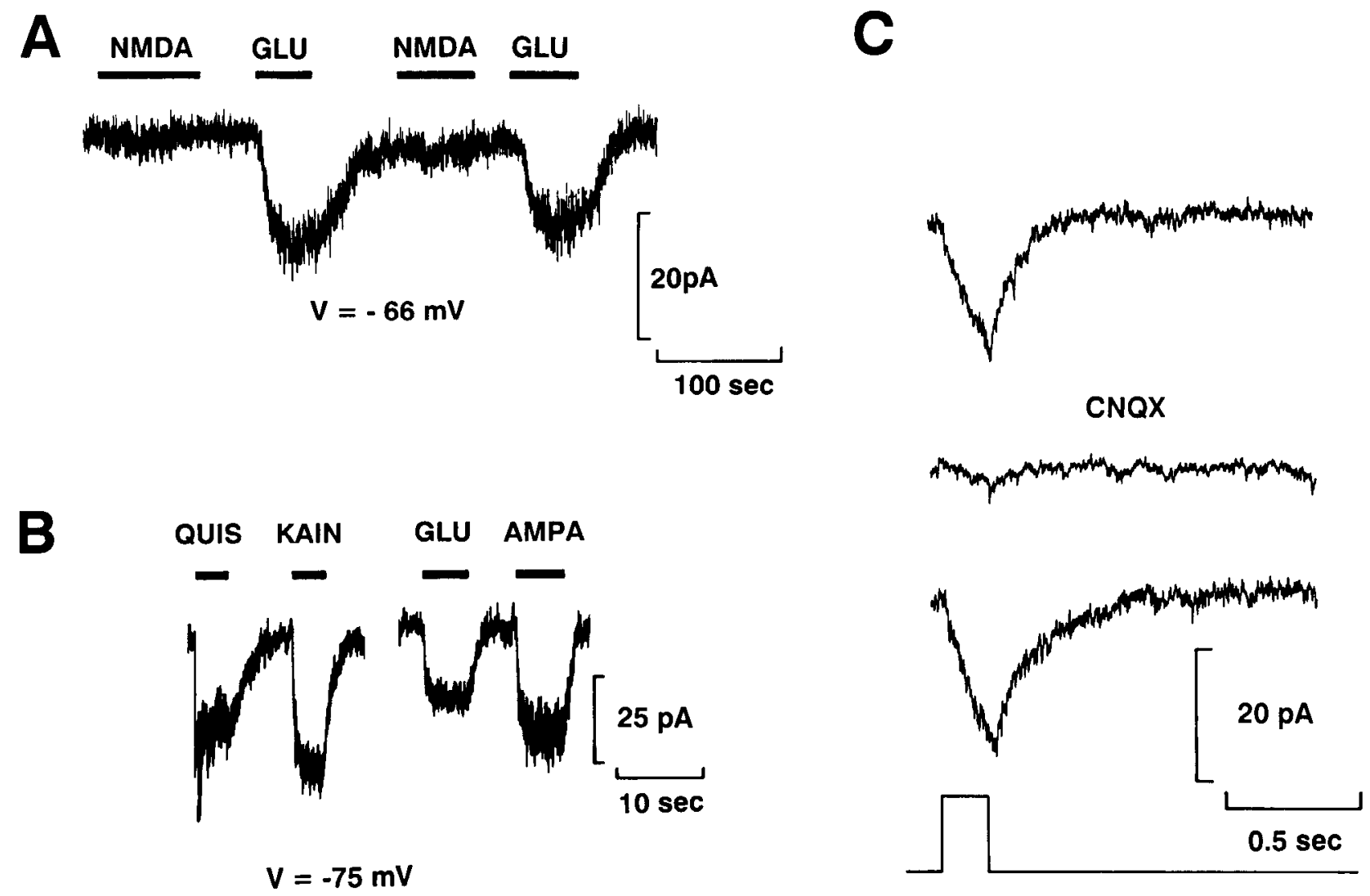

Figure 9. The pharmacology of the glutamate-evoked current. $A$, Whole-cell current responses of an astrocyte to application of $100 \mu \mathrm{M}$ glutamate $(G L U)$ and $100 \mu \mathrm{M}$ NMDA in the presence of $1 \mu \mathrm{M}$ glycine and the absence of $\mathrm{Mg}^{2+}$. Holding potential, $-66 \mathrm{mV}$. $B$, The responses of an astrocyte to the application of $100 \mu \mathrm{M}$ glutamate, kainate $(K A I N)$, quisqualate $(Q U I S)$, and AMPA at a holding potential of $-75 \mathrm{mV}$. $C$, The current evoked by glutamate is blocked by CNQX. The traces show the response of an astrocyte to ionophoretic application of glutamate at a holding potential of $-74 \mathrm{mV}$ : in Ringer's (top), in Ringer's plus $20 \mu \mathrm{M}$ CNQX (middle), and on return to Ringer's solution (bottom). The top and bottom traces are averages of 12 responses, and the middle trace is the average of 6 responses. The timing of the ionophoretic pulse (holding current, $+30 \mathrm{nA}$; eject current, $-30 \mathrm{nA}$ ) is shown at the bottom of the figure.

\section{Discussion}

Effects of the presence of GABA- and glutamate-gated channels on resting potential and potassium regulation

In this study we have shown that GABA- and glutamate-gated channels exist in the membranes of rabbit visual streak astrocytes. The high percentage of cells responding to each of the transmitters shows that receptors for GABA and glutamate must coexist in the majority of these cells.

The membrancs of rabbit visual streak astrocytes are exposed to the vitreous humor. Studies of the amino acid content of the rabbit vitreous have shown that glutamate and GABA are present at concentrations of between 10 and $170 \mu \mathrm{M}$ and 1 and 15 $\mu \mathrm{M}$, respectively (see above). These concentrations of glutamate and GABA will induce significant conductance changes in the astrocyte membrane, $10 \mu \mathrm{M}$ glutamate and $1 \mu \mathrm{M} \mathrm{GABA}$ evoking conductance increases equivalent $1022 \%$ and $131 \%$, respectively, of the cell's resting conductance.

It is normally assumed that the resting potential of astrocytes is largely determined by their resting conductance to potassium. However, the results presented here suggest that channels operated by glutamate and GABA will be tonically activated and this may play a major role in determining the resting potential of visual streak astrocytes in vivo. The reversal potential for the glutamate-evoked current for normal internal and external ion concentrations lies near $0 \mathrm{mV}$ (Hablitz and Langmoen, 1982); any glutamate present in the vitreous will depolarize the cells from the resting potential measured in isolated retinas perfused with Ringer's solution. However, the chloride equilibrium potential in glial cells lies near the resting potential (Ballanyi et al., 1987), and thus tonic activation of GABA receptors will tend to counteract the effects of glutamate. These results may be important for astrocytes elsewhere in the nervous system because astrocytes from a variety of sources have been shown to express glutamate-gated ion channels in culture. The microdialysis experiments of Graham et al. (1990) and Hagberg et al. (1985) show that GABA and glutamate are present in the extracellular space of the CNS at concentrations of between 0.2 and $1 \mu \mathrm{M}$ and 1.5 and $9 \mu \mathrm{M}$, respectively, these levels rising several fold during periods of anoxia.

The presence of GABA and glutamate in the vitreous will affect the way in which astrocytes handle potassium when it becomes elevated during neuronal activity or periods of ischemia. Raised external potassium will lead to potassium accumulation in addition to the redistribution predicted by the "spatial-buffering hypothesis" (Orkand et al., 1966; Gardner-Medwin, $1983 a, b)$ for cells with a potassium-specific membrane. In the presence of GABA, the movement of potassium into retinal astrocytes will be accompanied by the influx of chloride and water, leading to swelling, the GABA-operated channels fulfill- 

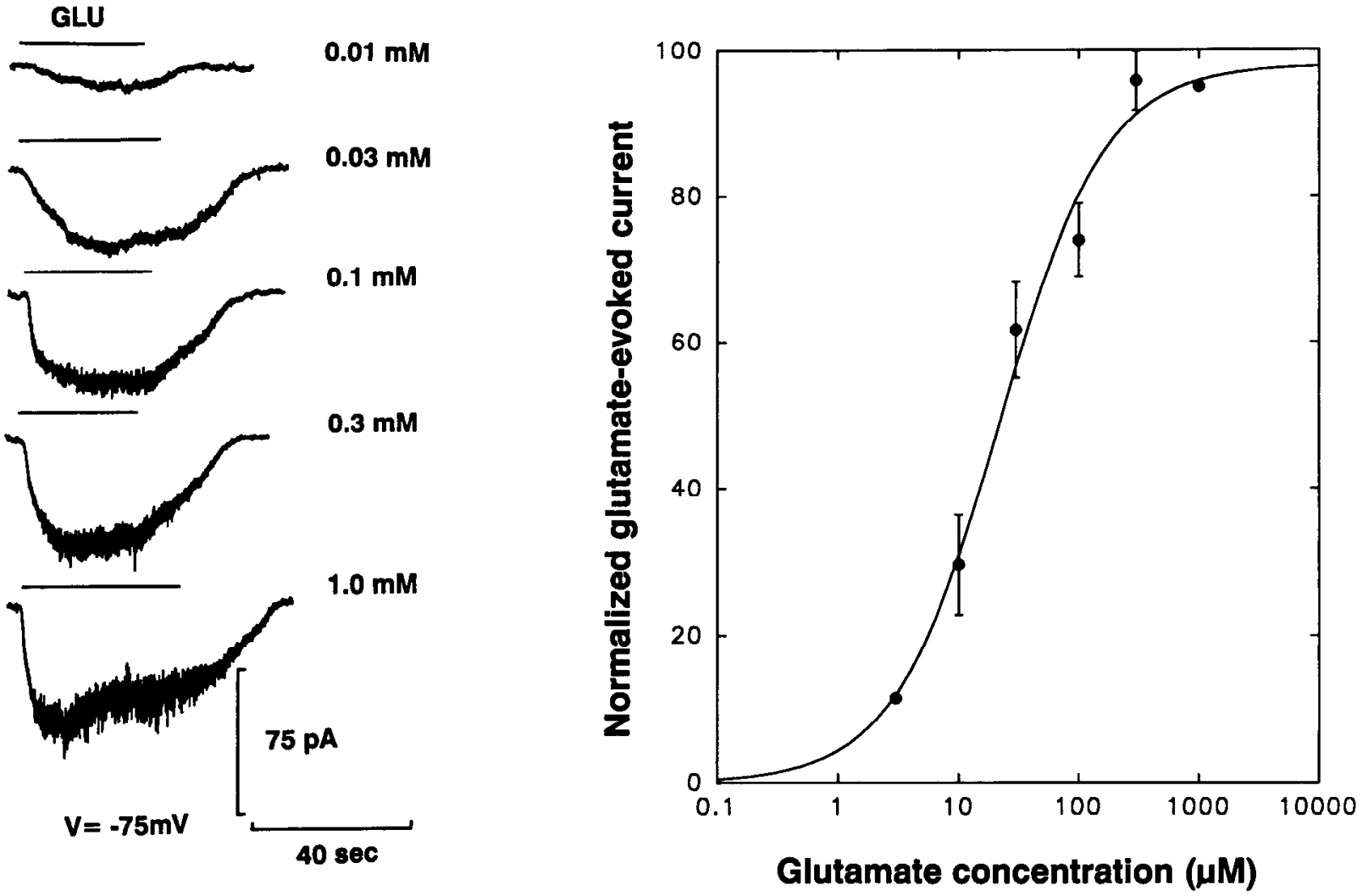

Figure 10. The glutamate dose-response relationship. $A$, The responses of an astrocyte to the application of glutamate at a series of increasing concentrations at a holding potential of $-75 \mathrm{mV}$. The timing of glutamate application is shown by the $b a r$ above each trace. $B$, A dose-response curve produced from a series of experiments like that shown in $A$. Each point is the mean of three cells (points at 3 and $1000 \mu \mathrm{M}$ are the mean of two cells). The bars indicate SE. The line through the data is a least-squares fit of the logistic equation (see Fig. 5 caption) with $\mathrm{EC}_{50}=21.5 \mu \mathrm{M}$ and a Hill slope of 2 .

ing a role similar to that suggested by Gray and Ritchie (1986) for the voltage-gated chloride channels present in cultured rat astrocytes.

\section{The role of glial transmitter-gated channels in intercellular signaling}

Several interesting putative functions have been suggested for glutamate-operated channels in astrocytes. These include signaling between neurons and glial cells, glial cells and other glial cells, and glial cells and capillary endothelial cells (for review, see Barres et al., 1990a,b).

Neuronal-glial signaling has been suggested for sites at which glutamate is released along the length of axons as has been demonstrated for the squid giant axon (Lieberman et al., 1989) and vertebrate and invertebrate nerve trunks (Wheeler et al., 1966; Weinreich and Hammerschlag, 1975). If glial cells at sites of axonal glutamate release have glutamate receptors, then it has been suggested that they might serve to regulate neuronal excitability via changes in the concentrations of $\mathrm{Na}^{+}$and $\mathrm{K}^{+}$in the extracellular space of active nerve cell membrane (Usowicz et al., 1989). This is a possible function for the glutamate receptors of astrocytes in the rabbit visual streak because some of these cells' processes make close contact with bundles of myelinated ganglion cell axons; ganglion cells are thought to use glutamate as a transmitter (Ehinger et al., 1988; Marc et al., 1989).

In hippocampal and cortical astrocytes there is evidence from calcium-imaging experiments that glutamate receptor activation in these cells leads to an increase in internal calcium; this is thought to occur via a "metabotropic" receptor linked to the production of inositol-1,4,5-trisphosphate and diacylglycerol (Cornell-Bell and Finkbeiner, 1991). Glutamate-evoked oscillations in internal calcium propagate between astrocytcs in confluent culture and may form the basis of a long-range signaling mechanism between glial cells (Cornell-Bell et al., 1990). We do not believe that the glutamate-evoked current seen in our cells is due to the activation of a metabotropic receptor because the metabotropic agonist trans-ACPD was without effect on the membrane current.

The possibility that glial cells form a link between neuronal activity and the vascular system remains to be demonstrated. However, the possibility that increased metabolic activity in neurons is linked to an increase in regional blood flow via the release of either neuronal potassium or neurotransmitters such as GABA and glutamate is worthy of further investigation. $\mathrm{K}^{+}$, which is released from astrocyte endfeet (Newman et al., 1984; Paulson and Newman, 1987) that lie near blood vessels, could potentially form the messenger in any such interaction. 


\section{References}

Ballanyi K, Grafe P, ten Bruggencate G (1987) Ion activities and potassium uptake mechanisms of glia cells in guinea-pig olfactory cortex slices. J Physiol (Lond) 382:159-174.

Barbour B, Brew H, Attwell D (1991) Electrogenic uptake of glutamate and aspartate into glial cells isolated from the salamander (Ambystoma). J Physiol (Lond) 436:169-193.

Barres BA, Chun LLY, Corey DP (1988) Ion channel expression by white matter glia: I. Type 2 astrocytes and oligodendrocytes. Glia 1: 10-30.

Barres BA, Koroshetz WJ, Swartz KJ, Chun LLY, Corey DP (1990a) Ion channel expression by white matter glia: the O-2A glial progenitor cell. Neuron 4:507-524.

Barres BA, Koroshetz WJ, Chun LLY, Corey DP (1990b) Ion channel expression by white matter glia: the type-1 astrocyte. Neuron 5:527544.

Bignami A, Dahl D (1977) Specificity of glial fibrillary acidic protein for astroglia. J Histochem Cytochem 25:466-469.

Bormann J, Kettenmann H (1988) Patch-clamp study of $\gamma$-aminobutyric acid receptor chloride channels in cultured astrocytes. Proc Natl Acad Sci USA 85:9336-9340.

Bormann J, Hamill OP, Sakmann B (1987) Mechanism of anion permeation through channels gated by glycine and $\gamma$-aminobutyric acid in mouse cultured spinal neurons. J Physiol (Lond) 385:243-286.

Brew H, Attwell D (1987) Electrogenic glutamate uptake is a major current carrier in the membrane of axolotl retinal glial cells. Nature 327:707-709.

Clark B, Mobbs P (1990) A flat-mount preparation of the rabbit retina for whole-cell patch-clamp studies of capillary endothelial cells, pericytes and astrocytes. J Physiol (Lond) 426:7P

Cornell-Bell AH, Finkbeiner SM (1991) $\mathrm{Ca}^{2+}$ waves in astrocytes. Cell Calcium 12:185-204.

Cornell-Bell AH, Finkbeiner SM, Cooper MS, Smith SJ (1990) Glutamate induces calcium waves in cultured astrocytes: long-range glial signalling. Science 247:470-473.

Cull-Candy SG, Howe JR, Ogden DC (1988) Noise and single channels activated by excitatory amino acids in rat cerebellar granule neurons. J Physiol (Lond) 400:189-222.

Ehinger B, Ottersen OP, Storm-Mathisen J, Dowling JE (1988) Bipolar cells in the turtle retina are strongly immunoreactive for glutamate. Proc Natl Acad Sci USA 85:8321-8325.

Fenwick EM, Marty A, Neher E (1982) A patch-clamp study of bovine chromaffin cells and of their sensitivity to acetylcholine. J Physiol (Lond) 331:577-597.

Gardner-Medwin AR (1983a) A study of the mechanisms by which potassium moves through brain tissue in rat. $\mathbf{J}$ Physiol (Lond) 335: 353-374.

Gardner-Medwin AR (1983b) Analysis of potassium dynamics in mammalian brain tissue. J Physiol (Lond) 335:393-426.

Graham SH, Shiraishi K, Panter SS, Simon RP, Faden AI (1990) Changes in extracellular amino acid neurotransmitters produced by focal cerebral ischemia. Neurosci Lett 110:124-130.

Gray PTA, Ritchie JM (1986) A voltage-gated chloride conductance in rat cultured astrocytes. Proc $R$ Soc Lond [Biol] 228:267-288.

Gunnarson G, Jakobsson A-K, Hamberger A, Sjöstrand J (1987) Free amino acids in the pre-retinal vitreous space. Effect of high potassium and nipecotic acid. Exp Eye Res 44:235-244.

Hablitz JJ, Langmoen IA (1982) Excitation of hippocampal pyramidal cells by glutamate in the guinea-pig and rat. J Physiol (Lond) 325: 317-331.

Hagberg H, Lehmann A, Sandberg M, Nyström B, Jacobson I, Hamberger A (1985) Ischaemia induced shift of inhibitory and excitatory amino acids from intra- and extracellular compartments. J Cereb Blood Flow Metab 5:413-419.

Hertz L (1979) Functional interactions between neurons and astrocytes. 1 . Turnover and metabolism of putative amino acid transmitters. Prog Neurobiol 13:277-323.

Ketlenmann H, Schachner M (1985) Pharmacological properties of $\gamma$-aminobutyric acid-, glutamate-, and aspartate-induced depolarisations in cultured astrocytes. J Neurosci 5:3295-3301.
Krnjević K, Schwartz S (1967) Some properties of unresponsive cells in the cerebral cortex. Exp Brain Res 3:320-336.

Leiberman EM, Abbot NJ, Hassan S (1989) Evidence that glutamate mediates axon to Schwann cell signalling in the squid. Glia 2:94-102.

Lightman S, Mobbs P (1990) The capillaries of the rabbit retina visual streak: part of the blood-retina barrier accessible for patch-clamp studies. I Physiol (Lond) 423:45P.

Malchow RP, Ripps H (1990) The effects of $\gamma$-aminobutyric acid on skate retinal horizontal cells: evidence for an electrogenic uptake mechanism. Proc Natl Acad Sci USA 87:8945-8949.

Malchow RP, Qian H, Ripps H (1989) $\gamma$-Aminobutyric acid (GABA)induced currents of skate Müller (glial) cells are mediated by neuronal-

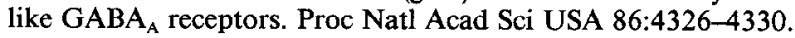

Marc RE, Massey SC, Kalloniatis M, Basinger SF (1989) Immunochemical evidence that the fast neurotransmitter of rods, cones, bipolar and ganglion cells is glutamic acid. Invest Opthalmol [Suppl] 30:320.

Newman EA, Frambach DA, Odette LL (1984) Control of extracellular potassium levels by retinal glial cell $\mathrm{K}^{+}$siphoning. Science $225: 1174$ 1175.

Orkand RK, Nicholls JG, Kuffler SW (1966) Effects of nerve impulses on the membrane potential of glial cells in the central nervous system of amphibians. J Neurophysiol 29:788.

Paulson OP, Newman EA (1987) Does the release of potassium from astrocyte endfeet regulate cerebral blood flow? Science 237:896-898.

Raff MC, Miller RH, Noble M (1983) A glial progenitor cell that develops in vitro into an astrocyte or oligodendrocyte depending on the culture medium. Nature 303:390-396.

Reddy DVN, Rosenberg C, Everett Kinsey V (1961) Steady state distribution of free amino acids in the aqueous humours, vitreous body and plasma of the rabbit. Exp Eye Res 1:175-181.

Robinson SR, Dreher Z (1989) Evidence for three morphological classes of astrocyte in the adult rabbit retina: functional and developmental implications. Neurosci Lett 106:261-268.

Sarantis M, Attwell D (1990) Glutamate uptake in mammalian retinal glia is voltage- and potassium-dependant. Brain Res 516:322-325.

Schnitzer J, Karschin A (1986) The shape and distribution of astrocytes in the retina of the adult rabbit. Cell Tissue Res 246:91-102.

Schwartz EA (1987) Depolarisation without calcium can release $\gamma$-aminobutyric acid from a retinal neuron. Science 238:350-355.

Sontheimer H, Kettenman H, Backus KH, Schachner M (1988) Glutamate opens $\mathrm{Na}^{+} / \mathrm{K}^{+}$channels in cultured astrocytes. Glia $1: 328$ 336.

Stensaas LJ (1975) Pericytes and perivascular microglial cells in the basal forebrain of the neonatal rabbit. Cell Tissue Res 158:517-541.

Szatkowski M, Barbour B, Attwell D (1990) Non-vesicular release of glutamate from glial cells by reversed glutamate uptake. Nature 348: 443-446.

Tessier-Lavigne M, Attwell D, Mobbs P, Wilson M (1988) Membrane currents in retinal bipolar cells of the axolotl. J Gen Physiol 91:4972.

Usowicz MM, Gallo V, Cull-Candy SG (1989) Multiple conductance channels in type- 2 cerebellar astrocytes activated by excitatory amino acids. Nature 339:380-383.

Watanabe T, Raff MC (1988) Retinal astrocytes are immigrants from the optic nerve. Nature 332:834-837.

Watkins JC, Krogsgaard-Larsen P, Honoré T (1990) Structure-activity relationships in the development of excitatory amino acid receptor agonists and competitive antagonists. Trends Pharmacol Sci 11:2533.

Weinreich D, Hammerschlag R (1975) Nerve impulse-enhanced release of amino acids from non-synaptic regions of peripheral and central nerve trunks of bullfrog. Brain Res 84:137-142.

Wheeler DD, Boyarski LL, Brooks WH (1966) The release of amino acids from nerve during stimulation. J Cell Physiol 67:141-148.

Wyllie DJA, Mathie A, Symonds CJ, Cull-Candy SG (1991) Activation of glutamate receptors and glutamate uptake in identified macroglial cells in rat cerebellar cultures. J Physiol (Lond) 432:235-258. 